\begin{tabular}{|c|c|c|}
\hline Beitr. Ent. & Keltern & ISSN 0005-805X \\
\hline $53(2003) 2$ & S. 239-250 & 15.12 .2003 \\
\hline
\end{tabular}

\title{
New species and records of Leptusa KRAATZ from the Iberian peninsula
}

\section{(Insecta: Coleoptera: Staphylinidae, Aleocharinae)}

With 13 figures and 1 map

VOLKER ASSING

\section{Summary}

Two species of Leptusa KRAATZ are described from northwestern Spain: L. (Pisalia) cavata sp. n. and $L$. (Gnopberopisalia) cremata sp. n. Their facies and sexual characters are illustrated. New distribution data are presented for 16 species, most of which have not been recorded since their original descriptions, including the first record of $L$. nigerrima from Portugal.

Key words

Coleoptera - Staphylinidae - Aleochatinae - Leptusa - Palaearctic - Europe - Spain - Portugal - taxonomy new species - new records

\section{Zusammenfassung}

Zwei Arten der Gattung Leptusa KRAATZ werden aus dem nordwestlichen Spanien beschrieben: L. (Pisalia) cavata sp. n. und $L$. (Gnopheropisalia) cremata sp. n. Der Habitus sowie primäre und sekundäre Geschlechtsmerkmale werden abgebildet. Von 16 Arten werden neue Funddaten gemeldet, darunter ein Erstnachweis von $L$. nigerrima für Portugal.

\section{Introduction}

Leptusa KRAATZ is one of the most diverse genera of Staphylinidae in the Western Palaearctic region; the vast majority of the species are more or less endemic. In the Iberian peninsula the genus is represented by 30 endemic species ( 34 species and subspecies), all of them confined to northern Spain and the northern half of Portugal. No endemic Leptusa species have become known from the south of the Iberian peninsula (ASSING, 2002; PACE 1989, 1996, 1999; PAŚNIK 1998). One of the species described from northern Spain may be synonymous, but this can be verified only based on a study of types (see remarks below L. cantabrica).

In recent years, abundant new material of Staphylinidae has become available from Spain and Portugal, mainly through several field trips organized by various German colleagues. A study of this material has yielded numerous new species especially from the north of the Iberian peninsula (e. g. ASSING, 1996, 2000, 2003; FELDMANN 2000a, 2000b; WUNDERLE 1992; ZERCHE in prep.), even a new genus of Paederinae (ASSING \& FELDMLANN 2001), and has shown that our knowledge of the staphylinid fauna of the region is far 
from complete. It is, therefore, not surprising that a more extensive and specialized collecting activity also led to the discovery of new species of Leptusa. In view of the poor documentation of faunistic data for the Iberian peninsula, I use the opportunity to report additional records of described species. For details pertaining to a second record of L. reinosensis see Assing (2002).

\section{Material and measurements}

The material treated in this paper is deposited in the following institutions and private collections:

$\begin{array}{ll}\text { DEI } & \text { Deutsches Entomologisches Institut, Eberswalde (L. ZERCHE) } \\ \text { NHMW } & \text { Naturhistotisches Museum Wien (H. SCHILLHAMMER) } \\ \text { cAss } & \text { author's private collection } \\ \text { cFel } & \text { private collection B. FELDMANN, Münster } \\ \text { cWun } & \text { private collection P. WUNDERLE, Mönchengladbach }\end{array}$

\section{New records and species of Iberian Leptusa}

\section{Leptusa (Pisalia) tricolor SCRIBA}

\section{Material examined:}

Portugal: 18 exs., SW Montalegre, Parafita, 41 $45^{\prime} 35 \mathrm{~N}, 7^{\circ} 49^{\circ} 44 \mathrm{~W}, 902 \mathrm{~m}$, leaf litter near creek, 22.111 .2002 , leg. Meybohm (cAss); 8 exs., Portugal, Serra do Geres, SW Portela de Homem, 41 ${ }^{\circ} 47^{\prime} 37 \mathrm{~N}, 8^{\circ} 08^{\prime} 36 \mathrm{~W}$, $629 \mathrm{~m}$, Quercus and Laurus litter, 23.III.2002, leg. Lompe (cAss); 8 exs., Portela de Homem, 41'048'16N, $8^{\circ} 07^{\prime} 51 \mathrm{WW}, 752 \mathrm{~m}$, Quercus litter, 23.III.2002, leg. Lompe (cAss); 5 exs., E Portela de Homem, 41 ${ }^{\circ} 48^{\prime} 19 \mathrm{~N}$, $8^{\circ} 07^{\prime} 13 \mathrm{~W}, 785 \mathrm{~m}$, Quercus and Laurus litter, 23.III.2002, leg. Lompe (cAss); 1 ex., Serta do Geres, Portela do Homem, 700m, 19.V.1997, leg. Starke (cFel); 1 ex., Serra do Geres, Portela de Leonte, $41^{\circ} 46^{\circ} 02 \mathrm{~N}, 8^{\circ} 08^{\prime} 49 \mathrm{~W}$, $860 \mathrm{~m}$, under bushes near meadow, 22.III.2002, leg. Meybohm (cAss); 4 exs., Serra do Geres, Geres, $800 \mathrm{~m}$, 27.V.1992, leg. Wunderle (cAss); 7 exs., Serra da Peneda, Santuario da Peneda, $42^{\circ} 00^{\prime} 26 \mathrm{~N}, 8^{\circ} 12^{\prime} 31 \mathrm{~W}, 886 \mathrm{~m}$, mixed forest, 24.III.2002, leg. Lompe (cAss); 1 ex., Serra da Peneda, N Soajo, 41॰53'18N, $8^{\circ} 16^{\prime} 16 \mathrm{~W}, 525 \mathrm{~m}$, creek valley, 24.III.2002, leg. Meybohm (cAss); 12 exs., Vila Real, Serra do Marao, 750m, 21.V.1977, leg. Starke (cAss, cFel).

Leptusa tricolor is endemic in the Serra do Geres and adjacent mountain ranges (Serra da Peneda, Serra do Marao). The distributions of $L$. tricolor and $L$. leonica are apparently parapatric (see below).

\section{Leptusa (Pisalia) leonica PACE}

\section{Material examined:}

Portugal: 18 exs., Bragança, Serra de Bornes, $41^{\circ} 46^{\prime} 42 \mathrm{~N}, 7^{\circ} 01^{\circ} 01 \mathrm{~W}, 832 \mathrm{~m}$, creek valley with Rubus,

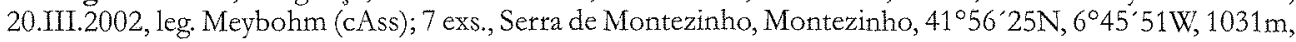

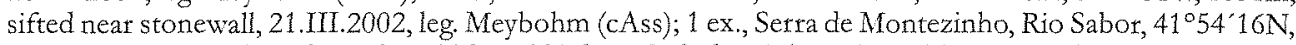
$6^{\circ} 48^{\prime} 23 \mathrm{~W}, 966 \mathrm{~m}$, edge of meadow, 21.MI.2002, leg. Meybohm (cAss); 5 exs., Tronco, E Chaves, $41^{\circ} 46^{\prime} 27 \mathrm{~N}$, $7^{\circ} 18^{\prime} 17 \mathrm{~W}, 842 \mathrm{~m}$, meadow, sifted near stonewall, 22.III.2002, leg. Meybohm (cAss). 
Leptusa leonica is relatively widespread, its distribution ranging from León province (NWSpain) to northern Portugal (PACE, 1989).

\section{Leptusa (Pisalia) inexpectata FAGEL}

\section{Material examined:}

Spain: 6 exs., Lugo, Sierra de Ancares, Degrada - Tres Obispos, 1100m, 17.V.1997 \& 30.V.1996, leg. Starke (cAss); 5 exs., Sierra de Ancares, Piomedo - Mustallar, 31.V.1996, leg. Starke (cAss); 3 exs., Sierra de Ancares, Piomedo, 1100m, 16.V.1997, leg. Starke (cFel); 11 exs., Sierra de Ancares, Degrada Monte da Vatg, 4249N, 653W, 29.V.1998, leg. Lompe (cAss); 4 exs., Galicia, Linares, $42^{\circ} 42 \mathrm{~N}, 7^{\circ} 04 \mathrm{~W}, 1000 \mathrm{~m}$, beech forest, 29.V.1998, leg. Lompe (cAss); 2 exs., Asturias, Puerto Ventana, $43^{\circ} 04 \mathrm{~N}, 6^{\circ} 01 \mathrm{~W}, 1200 \mathrm{~m}$, beech forest, 2.VI.1998, leg. Lompe (cAss); 35 exs., Asturias, Sierra de Rañadoiro, Puerto del Connio, $43^{\circ} 02^{\prime} 33 \mathrm{~N}, 6^{\circ} 43^{\circ} 08 \mathrm{~W}, 1300 \mathrm{~m}, 25$.VI.2002, leg. Assing (cAss).

Leptusa inexpectata has been recorded from various localities in the western Cordillera Cantabrica.

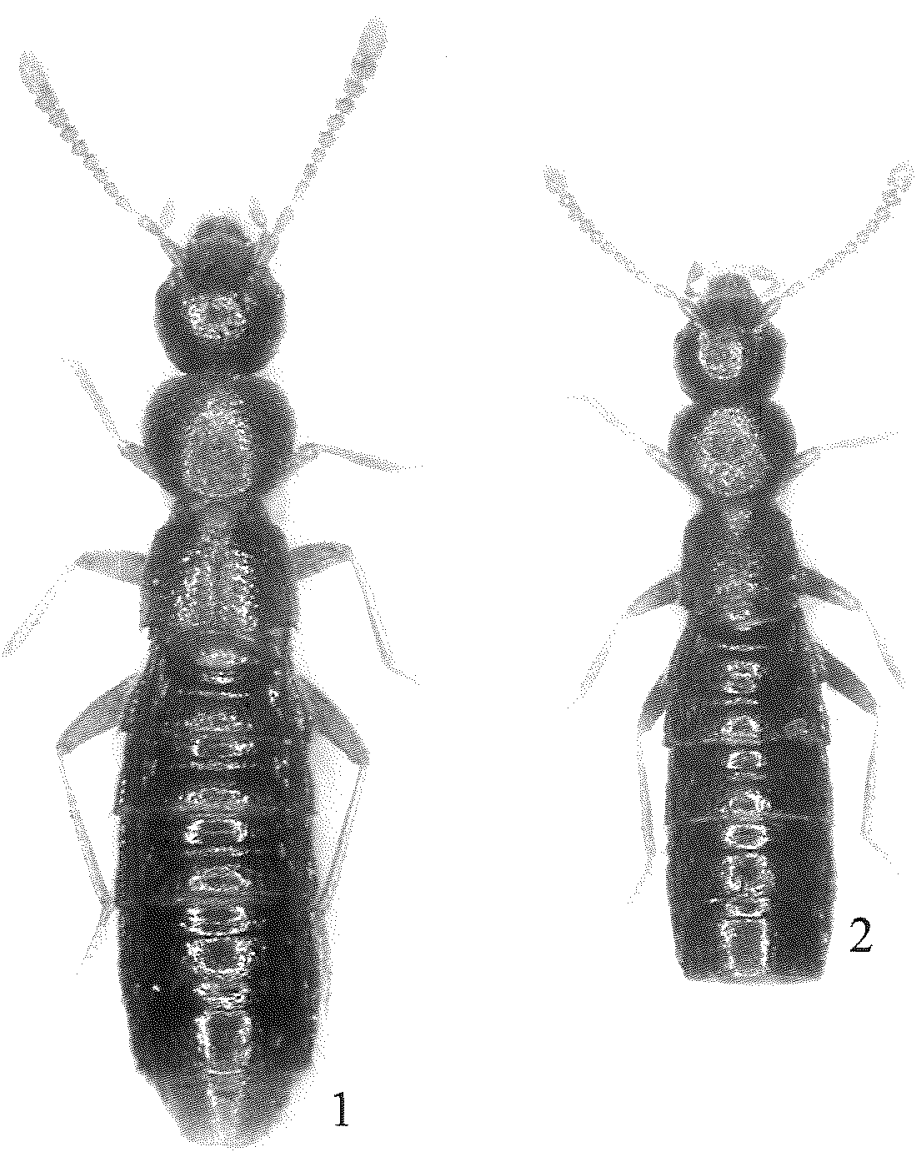

Figs. 1-2: Facies of Leptusa cavata sp. n. (1) and L. cremata sp. n. (2). 


\section{Leptusa (Pisalia) cavata sp. $\mathrm{n}$.}

(Figs. 1, 3-9)

\section{Types:}

Holotype o: E - León, 1, 25km SE Ponferrada, Montes de León, 1465m, Quercus, $42^{\circ} 29^{\prime} 35 \mathrm{~N}, 6^{\circ} 24^{\prime} 08 \mathrm{~W}, 21$.VI.2002, V. Assing / Holotypus ơ Leptusa cavata sp. n. det. V. Assing 2002 (cAss). Paratypes: $50^{\circ} 0^{\circ}, 3 \%$ : same data as holotype (NHMW, cAss, cWun).

\section{Description:}

$2.3-3.1 \mathrm{~mm}$. In general appearance highly similar to $L$. tricolor and $L$. leonica (Fig. 1). Forebody ferrugineous to brown, often with the head slightly darker; abdomen blackish, with the apex (posterior margin of segment VII and following segments) ferrugineous and with segments III and IV indistinctly lighter than V - VII; legs and antennae testaceous to light brown.

Head and pronotum of similar morphology as in $L$. tricolor, but puncturation much denser, shallower, and ill-defined; microsculpture more distinct. Elytra of similar shape and relative length as in $L$. tricolor, but puncturation much finer, not granulose. Abdomen, apart from the somewhat finer puncturation, as in $L$. tricolor. Posterior margin of abdominal tergite VIII in both sexes weakly concave in the middle (Fig. 7).

$\sigma^{*}$ : posterior margin of sternite VII broadly and deeply excavate; tergite VIII unmodified; posterior margin of sternite VIII pointed, in the middle with longer and stouter setae

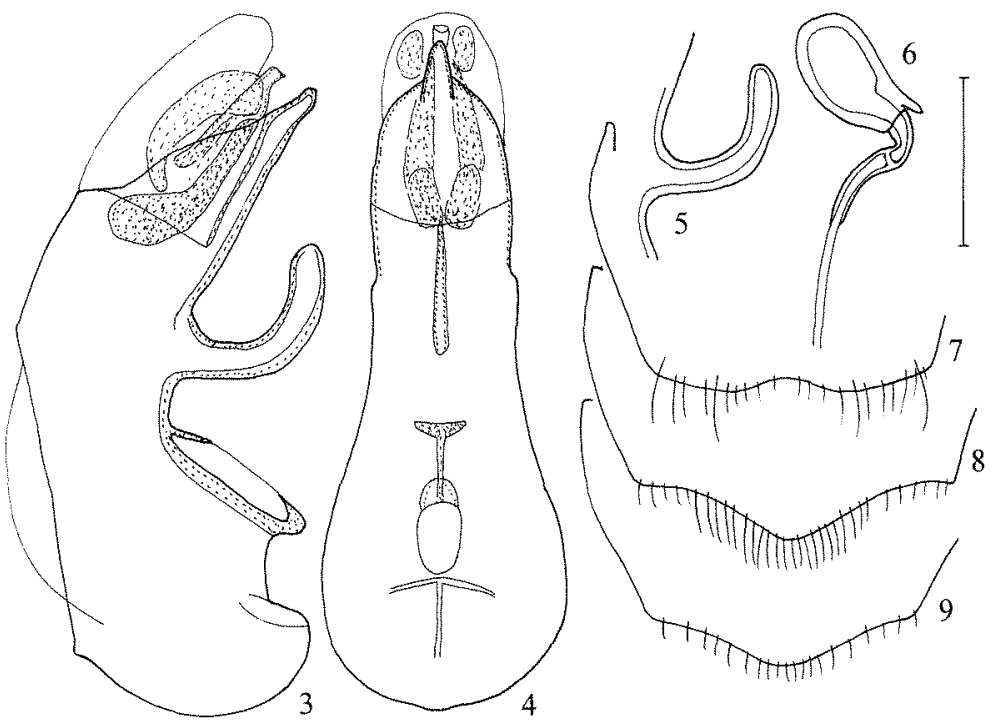

Figs. 3-9: Leptusa cavata sp. n.: median lobe of aedeagus in lateral and in ventral view $(3,4)$; process of median lobe of holotype in lateral view (5); spermatheca (6); posterior margin of of tergite VIII (7); posterior margin of $\sigma^{7}$ sternite VIII (8); postetior margin of of sternite VIII (9). Scale: 6: $0.08 \mathrm{~mm}$; 3-5: 0.1 mm; 7-9: $0.2 \mathrm{~mm}$. 
than laterally (Fig. 8); median lobe of aedeagus of distinctive shape, especially in lateral aspect (Figs. 3-5); apical lobe of paramere of similar shape and chaetotaxy as in other species of the subgenus.

ㅇ: sternite VIII posteriorly pointed, marginal setae much shorter and sparser than in 0 (Fig. 9); spermatheca as in Fig. 6.

Erymology: The name (Lat., adj.: excavate) refers to the deeply excavate posterior margin of the male sternite VII.

\section{Comparative notes:}

Leptusa cavata is distinguished from all other species of the subgenus by the morphology of the median lobe of the aedeagus, from $L$. tricolor and the externally similar $L$. leonica additionally by the deeply concave posterior margin of the male sternite VII and the less distinctly bicoloured abdomen. For more external characters separating the new species from $L$. tricolor see the description above. In $L$. deprebendens PACE, whose types (male holotype and two female paratypes in NHMW) were examined, the coloration is slightly lighter, the male sternite VII is highly distinctive (posterior margin with extremely deep and broad excavation, this excavation even deeper, broader, and of more trapezoid shape than in $L$. expectata, posterior margin as in L. expectata with extremely long marginal setae), and the aedeagus is of different morphology (see fig. 1159 in PACE, 1989).

\section{Distribution and bionomics:}

The type locality is situated in the region between Ponferrada and Astorga, at the pass between Manjarín and Foncebadón. The types were sifted from the litter layer of an oak forest in northern exposition with Erica undergrowth at an altitude of approximately $1460 \mathrm{~m}$.

\section{Leptusa (Pisalia) cantabtica PAŚNIK}

The species was recently described from the surroundings of Abiada (PAŚNIK, 1998) and erroneously attributed to the subgenus Neopisalia, which mainly includes species from the Caucasus region and which is absent from the Iberian peninsula. Doubtlessly, $L$. cantabrica is a representative of the $L$. tricolor species group of the subgenus Pisalia, whose distribution is confined to Spain and Portugal. The aedeagi of L. cantabrica PAŚNIK, 1998 and of L. tronqueti PACE, 1999 are highly similar, suggesting that the latter name may be a synonym of the former. However, the illustration of the aedeagus of $L$. cantabrica is too poor to be certain about this.

\section{Leptusa (Pachygastropisalia) lativentris SHARP}

\section{Material examined:}

Spain: $12 \sigma^{\circ}, 17 \% \circ$, Sierra de Ancares, Degrada Monte da Varg, 42 49N, 6053W, 29.V1998, leg. Lompe (cAss); $80^{\star}, 10$ 우, Sierra de Ancares, Piomedo - Mustallar, 1500m, 31.V.1996, leg. Starke (cAss); $1 \sigma^{*}$, Sierra de Ancares, Piomedo, 16.V.1997, leg. Starke (cFel); $90^{\circ} 0^{\circ}, 4 \% \%$, Sierra de Ancares, Degrada - Tres Obispos, 1600m, 30.V.1996 \& 17.V.1997, leg. Starke (cAss, cFel); 1 ex., Sierra de Courel, Liñares, 1200m, beechwood, 27.V.1996, leg. Aßmann (cFel); $10^{*}$, Asturias Puerto de Ventana, 4304N, $6^{\circ} 01 \mathrm{~W}, 1200 \mathrm{~m}$, beech forest, 2.VI.1998, leg. Lompe (cAss); $2090^{\circ} 0^{\prime}, 235 \%$ \%, Peña Ubiña, Puerto Ventana, $43^{\circ} 04^{\prime} 14 \mathrm{~N}$, 
$5^{\circ} 59^{\prime} 56 \mathrm{~W}, 1565 \mathrm{~m}$, Betula, Erica, 26.VI.2002, leg. Assing (cAss); $20^{\star} 0^{\star}, 7$ 우, Peña Ubiña, Puerto Ventana, $43^{\circ} 04^{\prime} 03 \mathrm{~N}, 5^{\circ} 59^{\prime} 13 \mathrm{~W}, 1870 \mathrm{~m}$, grass \& moss, 26.VI.2002, leg. Assing (cAss); $10^{\circ}$, Galicia, Linares, $42^{\circ} 42 \mathrm{~N}$, $7^{\circ} 04 \mathrm{~W}, 1000 \mathrm{~m}$, beech forest, 29.V.1998, leg. Lompe (cAss); 4 exs., Reinosa, Tres Mares - Cornon, 2000$2150 \mathrm{~m}, 4$.VI.1991, leg. Wunderle (cAss); $800^{\star}, 111 \% \&$, Asturias, Sierra de Rañadoiro, Puerto del Connio, $43^{\circ} 0233 \mathrm{~N}, 6^{\circ} 43^{\circ} 08 \mathrm{~W}, 1300 \mathrm{~m}, 25 . \mathrm{VI} .2002$, leg. Assing (cAss).

The species is widespread in the Cordillera Cantabrica and apparently abundant in montane and subalpine forests. Apart from the nominal subspecies, two additional subspecies have been described based on slight differences in the shape of the aedeagus. The material listed above is not sorted by subspecies, because it was not always possible to attribute the populations to any of them without doubt. More material and more biogeographical knowledge are needed to decide if the differences distinguishing the populations of $L$. lativentris are an expression of intersubspecific variation or if they are best interpreted as intraspecific, but not intersubspecific variation of a highly variable species.

\section{Leptusa (Lasiopisalia) europaea PACE}

Material examined:

Spain: $10^{*}, 1 \%$, Asturias, Picos de Europa, Sierra del Brazo, Cueva del Brazo, 1200m, beechwood, 4.VI.1998, leg. Hetzel (cFel).

The species was described only recently from Covadonga, to the northwest of the Picos de Europa (PACE, 1996).

\section{Leptusa (Gnopheropisalia) nigerrima PACE \\ (Map 1)}

\section{Types examined:}

Holotype o : Caboalles, Paganetti / ex coll. Scheerpeltz / Leptusa nigerrima m. / TYPUS

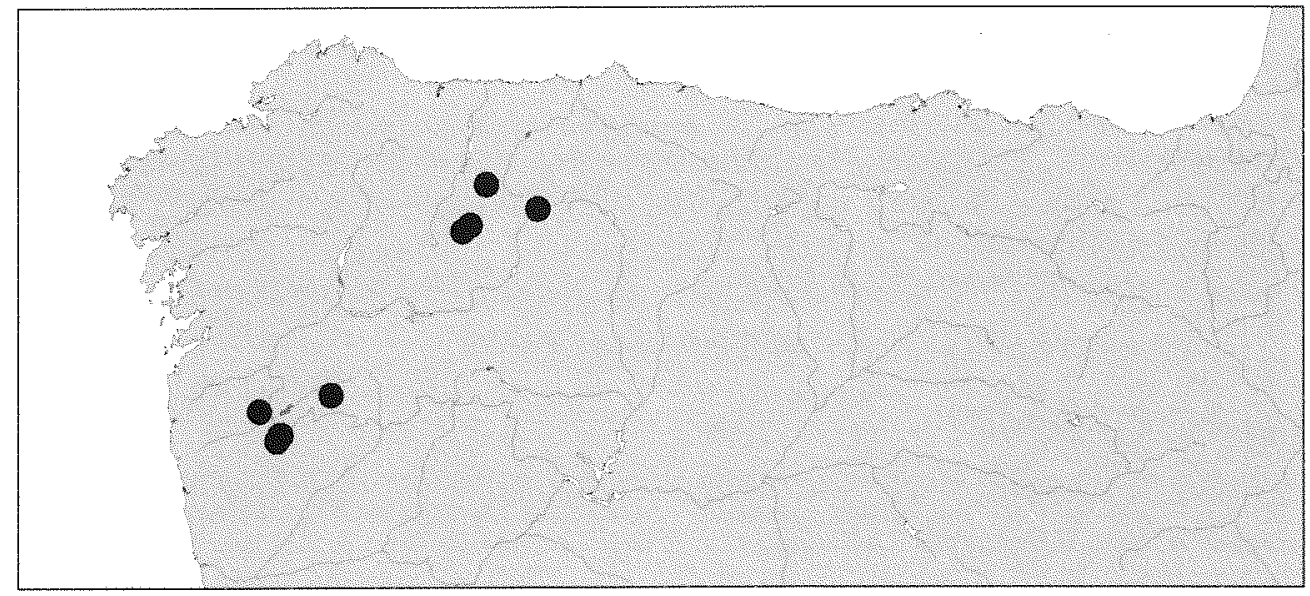

Map 1: Distribution of Leptusa nigerrima PACE. 
Leptusa nigerrima O. Scheerpeltz / HOLOTYPUS Leptusa (Tropidiopisalia) nigerrima m. det. R. PACE 1980 (NHMW). Paratypes: $10^{*}$ : Caboalles, Paganetti (NHMW); $10^{\star}$, 3 q q : Prov. Lugo, Hisp. bor. / Sierra de Ancares, Hisp. b., lg. H. Franz (NHMW).

Additional material examined:

Spain: $10^{\circ}$, Galicia, Sierra de Ancares, Degrada Monte da Varg, 42\%49N, 6053W, 29.V.1998, leg. Lompe

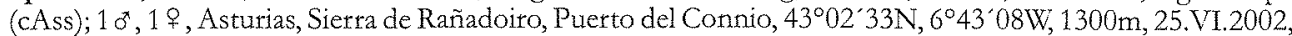
leg. Assing (cAss). Portugal: $10^{*}$, Serra da Peneda, N Soajo, 41.54 $33 \mathrm{~N}, 8^{\circ} 15^{\prime} 51 \mathrm{~W}, 639 \mathrm{~m}$, meadow, 24.III.2002, leg. Meybohm (cAss); $30^{\prime} 0^{*}, 1 \%$, Serra da Peneda, Santuario da Peneda, $42^{\circ} 00^{\prime} 26 \mathrm{~N}, 8^{\circ} 12^{\prime} 31 \mathrm{~W}$, $886 \mathrm{~m}$, mixed forest, 24.III.2002, leg. Meybohm (cAss); 5 우 오, Serra do Geres, Portela de Leonte, $41^{\circ} 46^{\prime} 02 \mathrm{~N}$, $8^{\circ} 08^{\prime} 49 \mathrm{~W}, 860 \mathrm{~m}$, under bushes near meadow, 22.\&23.111.2002, leg. Lompe, Meybohm (cAss); $20^{\star} o^{\star}, 1$, Serra do Geres, SW Portela de Homem, 41 $47^{\prime} 37 \mathrm{~N}, 8^{\circ} 08^{\prime} 36 \mathrm{~W}, 629 \mathrm{~m}$, Quercus and Laurus litter,

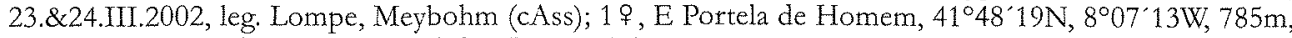
Quercus and Laurus litter, 23.III.2002, leg. Lompe (cAss).

Leptusa nigerrima was previously known from several localities in the western Cordillera Cantabrica; the species is here recorded from Portugal for the first time (Map 1).

\section{Leptusa (Gnopheropisalia) granulipennis EPPELSHEIM}

\section{Material examined:}

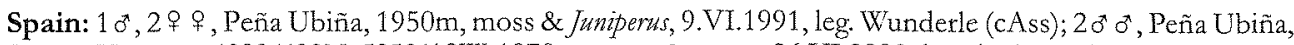

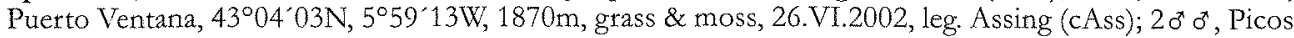
de Europa, Valle de Salvoron, 27.VII.1972, leg. Meybohm (cAss); 10 , Picos de Europa, Sierra del Brazo, Cueva del Brazo, $1200 \mathrm{~m}$, beechwood, 4.VT.1998, leg. Hetzel (cFel); $20^{\circ} 0^{\star}$. Asturias, $18 \mathrm{~km}$ N La Pola de

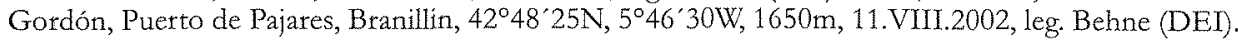

\section{Leptusa (Gnopheropisalia) cremata sp. n.}

(Figs. 2, 10-13)

\section{Types}

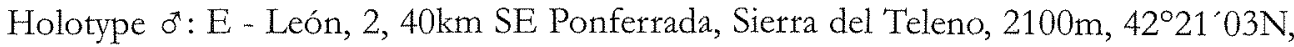
623'38W, 22. VI.2002, V. Assing/Holotypus o Leptusa cremata sp. n. det. V. Assing 2002 (cAss). Paratype 9 : same data as holotype (cAss).

\section{Description:}

$2.3-2.6 \mathrm{~mm}$. In general appearance very similar to $L$. nigerrima (Fig. 2). Body completely blackish, with the elytra only indistinctly lighter and the legs and antennae brown to dark brown.

Forebody of similar shape, proportions, puncturation, and microsculpture as in L. nigerrima. Head with extremely fine, barely noticeable puncturation and with very shallow microsculpture. Pronotum with more distinct, but ill-defined puncturation. Elytra with fine, weakly granulose puncturation. Legs, especially hind legs and metatarsi, shorter than in $L$. nigerrima. Abdomen with very weak transverse microsculpture and extremely fine puncturation. Tergite VIII in both sexes short, strongly transverse, and with truncate posterior margin. 

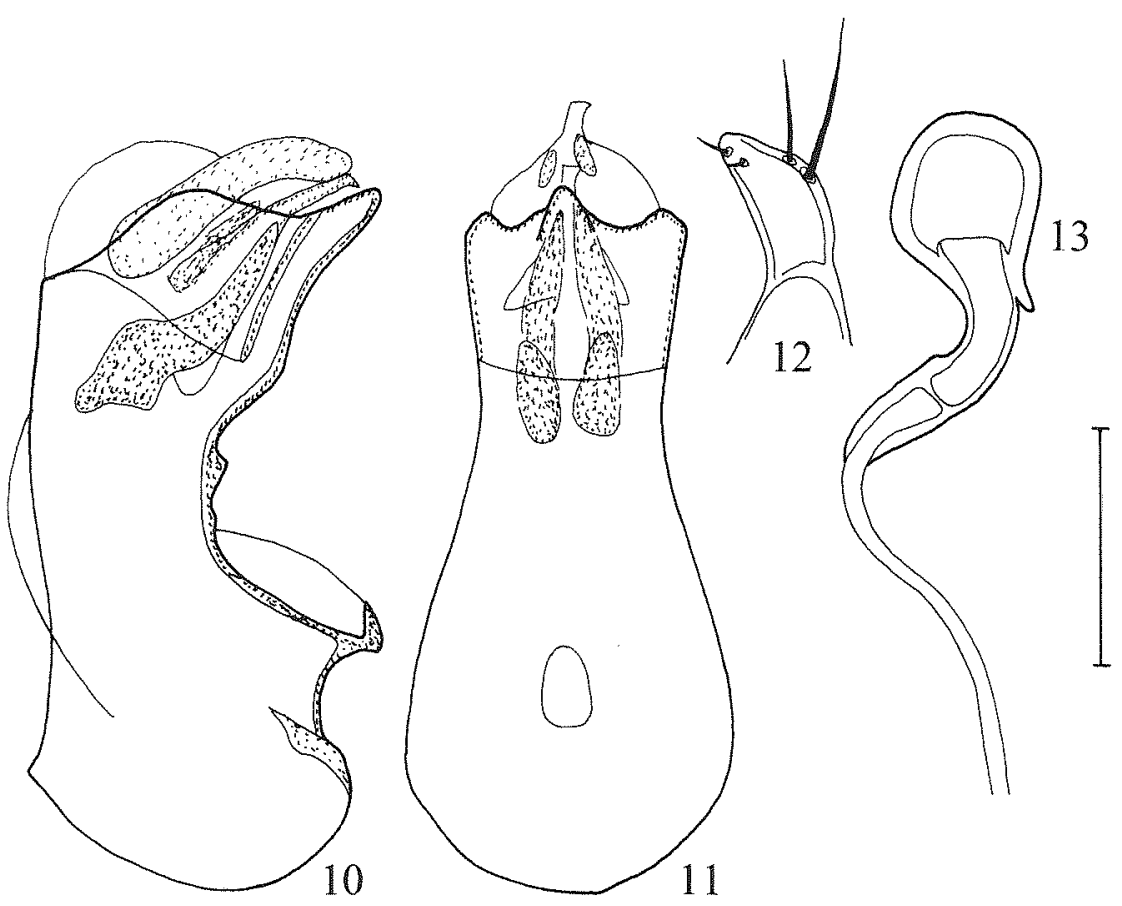

Figs. 10-13: Leptusa cremata sp. n.: median lobe of aedeagus in lateral and in ventral view (10, 11); apical lobe of paramere (12); spermatheca (13). Scale: 13: $0.08 \mathrm{~mm}$; 10-12: $0.1 \mathrm{~mm}$.

\$: tergite VIII unmodified; posterior margin of sternite VIII obtusely pointed and in the middle with rather long and dense marginal setae; median lobe of aedeagus of distinctive shape and with characteristic internal structures (Figs. 10-11); flagellum short; apical lobe of paramere as in Fig. 12.

F: posterior margin of sternite VIII convex, marginal setae shorter and sparser than in male; spermatheca as in Fig. 13.

Etymology: The name (Lat., adj.: burnt) refers to the dark coloration of this species.

\section{Comparative notes:}

Leptusa cremata is distinguished from the otherwise similar $L$. nigerrima especially by the shorter metatarsi and by the morphology of the median lobe of the aedeagus (ventral process in lateral view concave and more distant from crista apicalis, flagellum much shorter). Leptusa granulipennis, the only other congener of Gnopheropisalia occurring in the surroundings of Ponferrada, has testaceous legs and antennae, a more convex pronotum (cross-section), and a highly distinctive aedeagus, which is illustrated in PACE (1989). Leptusa (Gnopheropisalia) reinosensis PACE from the surroundings of Reinosa is of lighter coloration, larger, has strongly reduced eyes, modified male tergites VII and VIII, and an aedeagus of completely different shape (see PACE, 1996). 


\section{Distribution and bionomics:}

The type locality is situated in the Sierra del Teleno, near the peak of El Teleno. The types were sifted from litter of Erica and grass roots in the shade of big rocks at an altitude of $2100 \mathrm{~m}$.

\section{Leptusa (Entomophallopisalia) asturiensis EPPELSHEIM}

\section{Type examined:}

Holotype o: Asturias, Getschman, 1379, Reitter / asturiensis Eppelsh. Stett. Zeit. 1880, p. 282f / TYPUS / vidit R. Pace 1979 (NHMW).

Additional material examined:

Spain: $1 \sigma^{\circ}$, Lugo, Sierra de Ancares, Degrada, Tres Obispos, 1100m, VI.1997, leg. Balkenohl (cFel).

Previously, only the two type specimens from the vague type locality "Asturias" were known. The species is here recorded from the Sierra de Ancares. The relatively low altitude, at which it was collected, and the distributions of other Leptusa species in the region suggest that $L$. asturiensis may also occur in adjacent mountain ranges.

\section{Leptusa (Entomophallopisalia) cabrerensis PACE}

\section{Material examined:}

Spain: $100^{\top} \sigma^{\top}, 1^{\prime}$, León, 40km SE Ponferrada, Sierra del Teleno, $2100 \mathrm{~m}, 42^{\circ} 21^{\prime} 03 \mathrm{~N}, 6^{\circ} 23^{\prime} 38 \mathrm{~W}$, 22.VI.2002, leg. Assing (cAss); $40^{\circ} 0^{*}, 5^{\circ} 9$, León, Sierra de la Cabrera, $42^{\circ} 19^{\circ} 19 \mathrm{~N}, 6^{\circ} 43^{\prime} 50 \mathrm{~W}, 1770 \mathrm{~m}$, 24.VI.2002, leg. Assing (cAss).

Previously, only the holotype of this species was known (PACE, 1989). Leptusa cabrerensis is here recorded from the Sierra del Teleno for the first time, where it was collected together with $L$. franzi (see below) and $L$. cremata sp. $\mathrm{n}$. The material indicated above was sifted from grass roots, moss, and Erica litter in the shade of rocks at altitudes of 1770 and $2100 \mathrm{~m}$.

\section{Leptusa (Entomophallopisalia) franzi PACE}

Material examined:

Spain: $730^{\circ} 0^{\circ}, 59 \% q$, León, $40 \mathrm{~km}$ SE Ponferrada, Sierra del Teleno, $2100 \mathrm{~m}, 42^{\circ} 21^{\prime} 03 \mathrm{~N}, 6^{\circ} 23^{\prime} 38 \mathrm{~W}$, 22.VT.2002, leg. Assing (CAss); $60^{\star} 0^{\star}, 6$ o o , same data, but $42^{\circ} 21^{\prime} 13 \mathrm{~N}, 6^{\circ} 24^{\prime} 49 \mathrm{~W}, 1965 \mathrm{~m}$, (cAss); $20^{*} \sigma^{*}$,

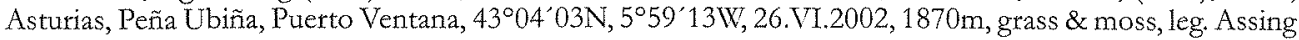
(cAss).

Leptusa franzi was previously known only from the type locality (Monte Teleno). In the Sierra del Teleno it is by far the most abundant Leptusa species in the alpine region. It was collected together with $L$. cremata, $L$. cabrerensis, and $L$. caboallensis in the Sierra del Teleno and with $L$. wunderlei and $L$. granulipennis in the Peña Ubiña. The material indicated above was sifted from grass roots, moss, and from litter of Erica and Betula in the shade of rocks at altitudes of $1870-2100 \mathrm{~m}$. 


\section{Leptusa (Entomophallopisalia) wunderlei PACE}

Material examined:

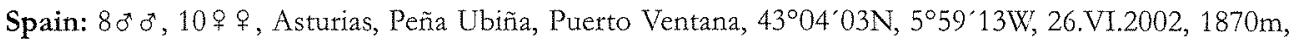
grass \& moss, leg. Assing (cAss).

L. wunderlei was described only recently (PACE, 1996) and has become known only from the Peña Ubiña. The specimens listed above were collected together with Leptusa lativentris and $L$. franzi by sifting grass roots and moss in the shade of big rocks.

\section{Leptusa (Entomophallopisalia) toscidavallensis PACE}

Material examined:

Spain: $10 \sigma^{*} \sigma^{*}$, Navarra, Ibaneta - Orzanzurieta, 1450m, 23.V.1997, leg. Starke (cAss, cFel); $270^{*}, 6 q q$, Navarra, Col de Ibaneta, Orzanzurieta, $43^{\circ} 01 \mathrm{~N}, 1^{\circ} 16 \mathrm{~W}, 1450 \mathrm{~m}$, beech forest, 28.V.1998, leg. Lompe (cAss); 1 ex., Col de Pierre S. Martin, 1600-1750m, 11.VI.1991, leg. Wunderle (cAss).

\section{Leptusa (Entomophallopisalia) caboallensis PACE}

\section{Types examined:}

Holotype ơ: Caboalles, Paganetti / ex coll. Scheerpeltz / asturiensis Epp. / det. Bernhauer / HOLOTYPUS Leptusa (Micropisalisa) asturiensis caboallensis m. det. R. PACE 1980 (NHMW). Paratype: 1 \% : Caboalles, Paganetti (NHMW).

Additional material examined:

Spain: $100^{\circ} 0^{*}$, León, 40km SE Ponferrada, Sierra del Teleno, 42 $21^{\prime} 13 \mathrm{~N}, 6^{\circ} 24^{\circ} 49 \mathrm{~W}, 1965 \mathrm{~m}, 22 . V I .2002$, leg. Assing (cAss); $20^{\circ} o^{\star}, 1 \%$, Asturias, Peña Ubiña, Puerto Ventana, $43^{\circ} 04^{\prime} 03 \mathrm{~N}, 5^{\circ} 59^{\prime} 13 \mathrm{~W}, 1870 \mathrm{~m}$, grass \& moss, 26.VI.2002, V. Assing (cAss).

\section{Distribution and bionomics:}

Leptusa caboallensis was previously known only from the type locality, but is evidently rather widespread, since (like $L$. franz?) it was found both in the Sierra del Teleno and in the Peña Ubiña. In the former it was found together with Leptusa franzi $i$ and in the latter together with $L$. wunderlei. The specimens were sifted from grass roots, moss, and birch litter at altitudes of 1870 and $1965 \mathrm{~m}$.

\section{Leptusa (Adexiopisalia) hummleri hummleri BERNHAUER}

\section{Types examined:}

Paralectotypes: $50^{\pi} \sigma^{*}, 60^{*}$ : Caboalles, Paganetti (NHMW).

Material examined:

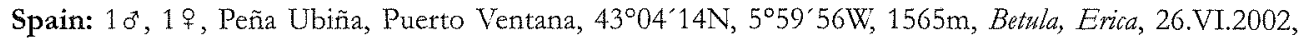
leg. Assing (cAss). 


\section{Comments:}

PACE (1989) designated a lectotype, so that the remaining syntypes are now paralectotypes. The nominal subspecies was previously recorded only from the type locality Caboalles and vaguely from "Asturie" (PACE, 1989). The new material was collected at Puerto Ventana (Peña Ubiña) together with almost 450 specimens of Leptusa lativentris by sifting leaf litter in a birch forest with Erica undergrowth at an altitude of $1565 \mathrm{~m}$.

\section{Leptusa (Adexiopisalia) hummleri advena PACE}

\section{Types examined:}

Holotype o: Umg. El Fito, W Aviles, Astur. / HOLOTYPUS Leptusa (Myopopisalisa) hummleri advena m. det. R. PACE 1980 (NHMW).

\section{Additional material examined:}

Spain: $20^{\circ} 0^{*}, 3 \% \%$, Asturias, Sierra de Rañadoiro, Puerto del Connio, $43^{\circ} 02^{\circ} 33 \mathrm{~N}, 6^{\circ} 43^{\circ} 08 \mathrm{~W}, 1300 \mathrm{~m}$, 25.V1.2002, leg. Assing (cAss).

\section{Comments:}

The description of this subspecies is unfortunately based on a single female from " $\mathrm{El}$ Fito" to the west of Avilés; the distinguishing characters indicated in the original description are rather vague: the shape of the head, a median furrow on the pronotum, and the shape of the apical cuticular intrusion of the spermathecal capsule. I have been unable to appreciate the external differences. However, the holotype is distinguished from the examined material of the nominal subspecies by slightly greater body size and by larger and pigmented eyes. (In L. bummleri bummleri, the pigmentation is practically obsolete.) No external differences were found between the additional material listed above and the holotype, so that these specimens are here attributed to $L . b$. advena, although the locality is separated by a considerable distance from the type locality. As in most other cases in which the descriptions of Leptusa species are based on females only, a reliable interpretation will be possible only when males from the type locality become available.

\section{Leptusa (Lasiopisalia) estrelensis PACE}

\section{Material examined:}

Portugal: $40^{\star} 0^{\star}$, Serra da Estrela, near Manteigas, X.1991, leg. Hernando (cAss); $50^{\star} 0^{\star}, 1$, Serra da Estrela, S Manteigas, $40^{\circ} 22^{\prime} 09 \mathrm{~N}, 7^{\circ} 33^{\circ} 04 \mathrm{~W}, 976 \mathrm{~m}$, Quercus litter, 18.111 .2002 , leg. Lompe (cAss); $110^{\circ} 0^{*}$, Serra da Estrela, W Manteigas, Penhas Douradas, $40^{\circ} 24^{\prime} 22 \mathrm{~N}, 7^{\circ} 33^{\prime} 56 \mathrm{~W}, 1469 \mathrm{~m}, 19.111 .2002$, leg. Lompe (cAss); $10^{*}$, Serra da Estrela, N Manteigas, $40^{\circ} 24^{\prime} 22 \mathrm{~N}, 7^{\circ} 31^{\prime} 44 \mathrm{~W}$, $849 \mathrm{~m}$, creek valley, 19.III.2002, leg. Meybohm (cAss).

Leptusa estrelensis is an endemic of the Serra da Estrela, where it is apparently very common in woodland at intermediate and higher altitudes. 


\section{Leptusa (Lasiopisalia) franziana franziana PACE}

\section{Material examined:}

Spain: $20^{*} o^{*}$, Sierra de Ancares, Piomedo - Mustallar, 1500m, 31.V.1996, leg. Starke (cAss); $10^{*}$, Sierra de

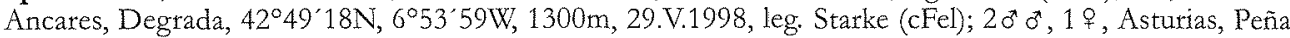
Ubiña, Puerto Ventana, 43004'14N, 559'56W, 1565m, Betula, Erica, 26.VI.2002, leg. Assing (cAss).

The subspecies was originally described as $L$. scheerpeltzi franqiana, but for reasons of priority the name had to be changed (Assing, 2002). Previously, only the types from the Sierra de Ancares were known (PACE, 1989).

\section{Acknowledgements}

I am most grateful to Benedikt Feldmann, Münster, for contributing additional records, to Harald Schillhammer, Wien, for the loan of some Leptusa material for comparison, as well as to my son Jan Hagen for his assistance, company, and patience.

\section{References}

Assing, V. 1996: The first species of Leptusina BERNHAUER from the Iberian Peninsula: Leptusina schuelkei spec. nov. (Insecta: Coleoptera: Staphylinidae: Aleocharinae). - Reichenbachia 31: 163-165.

ASSING, V. 2000: A new species of Cantaberella TRONQUET 1998 from northwestern Spain (Coleoptera: Staphylinidae, Aleocharinae). - Linzer biologische Beiträge 32: 79-84.

ASsING, V. 2002: New species and records of Leptusa KRAATZ from the Palaearctic region (Coleoptera: Staphylinidae, Aleocharinae). - Linzer biologische Beiträge 34 (2): 971-1019.

Assing, V. 2003: The first species of Tectusa BeRNHAuER from Portugal (Insecta: Coleoptera, Staphylinidae, Aleocharinae, Oxypodini). - Entomologische Abhandlungen 60: 129-132.

Assing, V. \& FELDMANN, B. 2001: A remarkable new European genus of Paederinae (Coleoptera, Staphylinidae). - Entomologische Blätter für Biologie und Systematik der Käfer, Keltern 97: 49-57.

FELDMANN, B. 2000a: Eine neue subanophthalme Art der Gattung Domene FAUVEL, 1872 aus dem nordwestlichen Spanien (Insecta: Coleoptera: Staphylinidae: Paederinae). - Reichenbachia 33: 327-331.

FELDMANN, B. 2000b: Eine neue Art der Gattung Stenus LATrEILle 1796 aus dem nordwestlichen Spanien (Insecta, Coleoptera, Staphylinidae: Steninae) - Linzer biologische Beiträge 32: 149-153.

PACE, R. 1989: Monografia del genere Leptusa KRAATZ (Coleoptera Staphylinidae). - Memorie del Museo Civico di Storia Naturale di Verona (II Serie), Sezione Scienze della Vita (A: Biologica) 8: 1-307.

PACE, R. 1996: Nuove Leptusa KraAtz di Spagna, Francia, Italia, Austria, Cipro, Turchia e Taiwan. Monografia del genere Lepiusa KRAATZ: Supplemento IV (Coleoptera, Staphylinidae). - Nouvelle Revue d'Entomologie, Nouvelle Série, Paris 13:21-33.

PACE, R. 1999: Leptusa tronqueti 1 . sp. della Spagna. Monografia del genere Leptusa KRAATZ: Supplemento IX (Coleoptera, Staphylinidae). - Nouvelle Revue d'Entomologie, Nouvelle Serié, Paris 16: 19-21.

PAŚNIK, G. 1998: A new species of the genus Leptusa from Spain (Coleoptera: Staphylinidae: Aleocharinae). - Acta zoologica cracoviensia, Kraków, 41: 191-193.

WunderLe, P. 1992: Domene (s. str.) zerchei n. sp., eine neue subanophthalme Art der Gattung Domene FAUVEL, 1873 aus dem nordwestlichen Spanien (Insecta, Coleoptera, Staphylinidae: Paederinae). Reichenbachia 29: 145-150.

\section{Authors' address:}

Dr. VOLKeR Assing, Gabelsbergerstraße 2, D-30163 Hannover, Germany e-mail: vassing. hann@t-online.de 